\title{
Facial visible spectrophotometric determination of metformin hydrochloride in glucosam tablets and industrial waste water: Application to content uniformity testing
}

\author{
Nief Rahman Ahmad* \\ *Department of Environmental Technology, College of Environmental and Technology, University of \\ Mosul
}

$\frac{\text { Received }}{3.7 .2011} \quad \frac{\text { Accepted }}{8.1 .2012}$

\section{ABSTRACT}

Objectives: To determine simple, accurate and highly sensitive spectrophotometric method for determination metformin hydrochloride in pharmaceutical preparations and in industrial waste water sample.

Materials and Method: The method is based on the oxidation of metformin by a known excess of sodium hypochlorite in alkaline medium.

Results: Formation of a yellow-colored chromophore having maximum absorbance at $385 \mathrm{~nm}$. Molar absorptivity was found to be $2 \times 10^{4} \mathrm{~L} \cdot \mathrm{mol}^{-1} \cdot \mathrm{cm}^{-1}$. Beer's law is obeyed in the concentration range of $0.5-4 \mu \mathrm{g} . \mathrm{ml}^{-1}$, relative standard deviation (RSD) is better than $\pm 1.8(\mathrm{n}=10)$. The limits of detection and quantitation are 0.083 and $0.25 \mu \mathrm{g} . \mathrm{mL}^{-1}$, respectively. The method is applied successfully to determination of metformin pharmaceutical formulation (tablets). The common excipients do not interfere with the proposed method. A statistical comparison of these results with those of official method using $\mathrm{t}$ and $\mathrm{F}$ values at $95 \%$ confidence level shows good agreements and indicated no significant difference in the precision, and the present method has good validity.

Conclusion: The proposed method can be used as a routine quality control and content uniformity tests for determination of metformin in pure form, tablet formulations and industrial waste water sample.

Keywords: Metformin hydrochloride, spectrophotometry, content uniformity.

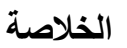

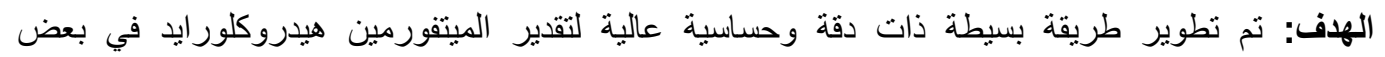

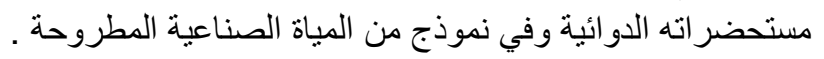

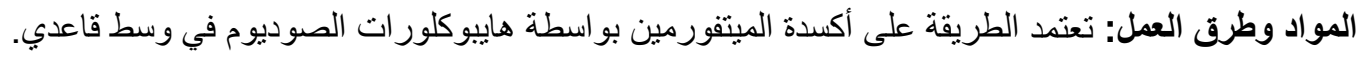

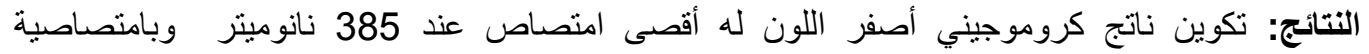

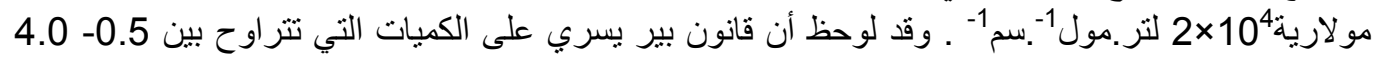

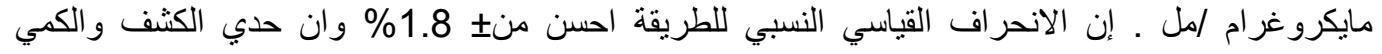

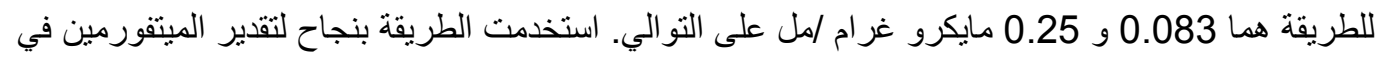

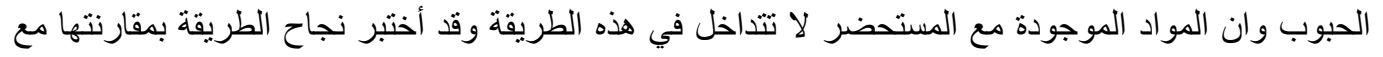

$$
\begin{aligned}
& \text { الطريقة القياسية الدستورية المعتمدة باستخدام اختباري (t) و) و(F) عند حدود ثقة }
\end{aligned}
$$

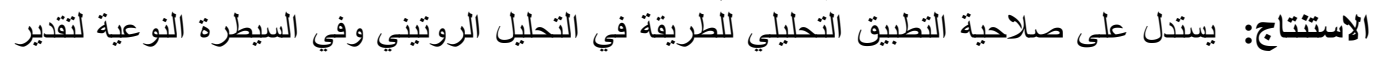

$$
\begin{aligned}
& \text { الميتفورمين بحالته النقية وفي مستحضر الحبوب وكذلك في نموذج من المياة الصناعية المطروحة فئنة }
\end{aligned}
$$


$\prod_{\text {(glucophage) }^{1},}^{\text {etformin }} \begin{array}{r}\text { hydrochloride } \\ \text { chemicals } 1,1-\end{array}$ Dimethyl biguanide hydrochloride with a molecular formula of $\mathrm{C}_{4} \mathrm{H}_{12} \mathrm{Cl}$ $\mathrm{N}_{5}$ (Fig 1). It is an oral antidiabetic drug that has been used in the treatment of non- insulin dependent diabetes which improves control of glycemia primarily by inhibiting hepatic gluconeogenesis and glycogenolysis $^{2}$ and seems to ameliorate hyperglycemia by improving preipheral sensitivity to insulin, reducing gastrointestinal glucose absorption and hepatic glucose production. Recently, metformin has also become available for the treatment of polycystic ovary syndrom and has been found to improve vascular function, prevent pancreatic cancer and revers fatty liver diseases $^{3}$.

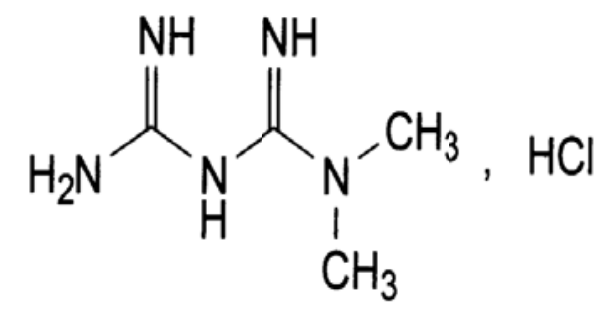

M. Wt $=165.6$

Fig 1. Chemical structure of metformin- $\mathrm{HCl}$.

Literature survey reveals that many HPLC methods for the detremination of metformin are reported. But most of the methods used either ion-pair reagent or cation exchange column ${ }^{4-15}$. Another different methods for the determination of metformin have been described, such as conductometric titration $^{16}$, flow-injection chemilumine- scence $^{17-19}$, capillary electrophoresis ${ }^{20}$, ion-selective electrode ${ }^{21}$ and adsorptive catalytic squar-wave voltammetry ${ }^{22}$. Very few spectrophotometric methods for the determination of metformin hydrochloride, in pharmaceutical formulation are described. The official method includes UV spectrophotometric method for estimation of the drug in the tablets ${ }^{23}$. The colorimetric methods include charge transfer complex with iodine in acetonitrile medium ${ }^{24}$, reaction of metformin with $\mathrm{Cu}^{+2}$ in basic cyclohexylamine medium ${ }^{25}$ and the reaction with ninhydrin to form a violet colored complex $^{26}$, and spectrophotometric method using multi variate technique ${ }^{27}$. However, all of these methods suffered from several disadvantages including use of complex extraction procedures which were tedious and time consuming, ultra filtration and column-switching technique, have been suggested to improve specificity and selectivity. The proposed method can be applicable to routine analysis and content uniformity test of metformin hydrochloride in tablets and complies well with the validation requirements in the pharmaceutical industry ${ }^{28}$.

\section{Material and methods}

\section{Apparatus}

A spectro scan 50 UV visible spectrophotometer with $1.0 \mathrm{~cm}$ quartz cells was used .

\section{Reagents}

All chemicals used were of analytical grade and the metformin hydrochloride standard material was provided from 
Ninevah drug industry and medical appliance (NDI), Iraq.

Metformin hydrochloride stock solution (100 ppm) was prepared by dissolving $0.1 \mathrm{~g}$ of metformin hydrochloride in $1 \mathrm{~L}$ distilled water in a volumetric flask.

Metformin hydrochloride standard solution (25 ppm) was prepared by diluting $25 \mathrm{~mL}$ of stock solution to 100 $\mathrm{mL}$ by distilled water in a volumetric flask.

Sodium hypochlorite solution (0.1\%) was prepared by dilution 1.25 $\mathrm{mL}$ of $8 \%$ sodium hypochlorite to 100 $\mathrm{mL}$ by distilled water, this solution was standardized every 4-5 days and stored in a dark bottle ${ }^{29}$.

Sodium hydroxide solution (10 N) Recommended procedure

Aliquots of standard solution of metformin hydrochloride (12.5-100 $\mu \mathrm{g})$ were transferred into a series of 25 $\mathrm{ml}$ calibrated flasks, $5 \mathrm{~mL}$ of $10 \mathrm{~N}$ sodium hydroxide and $2 \mathrm{~mL}$ of $0.1 \%$ sodium hypochlorite solution, and the solution was diluted to the mark with distilled water. The absorbance of the yellow-colored product was measured at $385 \mathrm{~nm}$ against a reagent blank.

\section{Procedure for pharmaceutical preparations (tablets)}

Weigh and powder 10 tablets. Dissolve a quantity of the powdered tablets containing $0.025 \mathrm{~g}$ of metformin hydrochloride in about 100 $\mathrm{mL}$ distilled water and mix for $20 \mathrm{~min}$ and then filtered. The filtrate was made up to $1 \mathrm{~L}$ with distilled water. Treat 3 $\mathrm{ml}$ of this solution as mentioned under recommended procedure.

\section{Procedure for industrial waste} water

To demonstrate the practical applicability of the proposed method, industrial waste water sample from the state company for drug industries and medical appliances, Mosul, Iraq, were analyzed by spiked with the concentrations ranging from 0.5-3.0 $\mu \mathrm{g} . \mathrm{mL}^{-1}$ of metformin hydrochloride and aliquot of this solution was treated as described above for recommended procedure.

\section{Results and discussion}

Metformin hydrochloride is oxidized in alkaline medium by sodium hypochlorite solution forming a yellow-colored chromophore which absorbs maximally at $385 \mathrm{~nm}$ as shown in Figure 2. The colorless reagent blank has practically negligible absorbance at this wavelength and this wavelength was recommended for determination. 


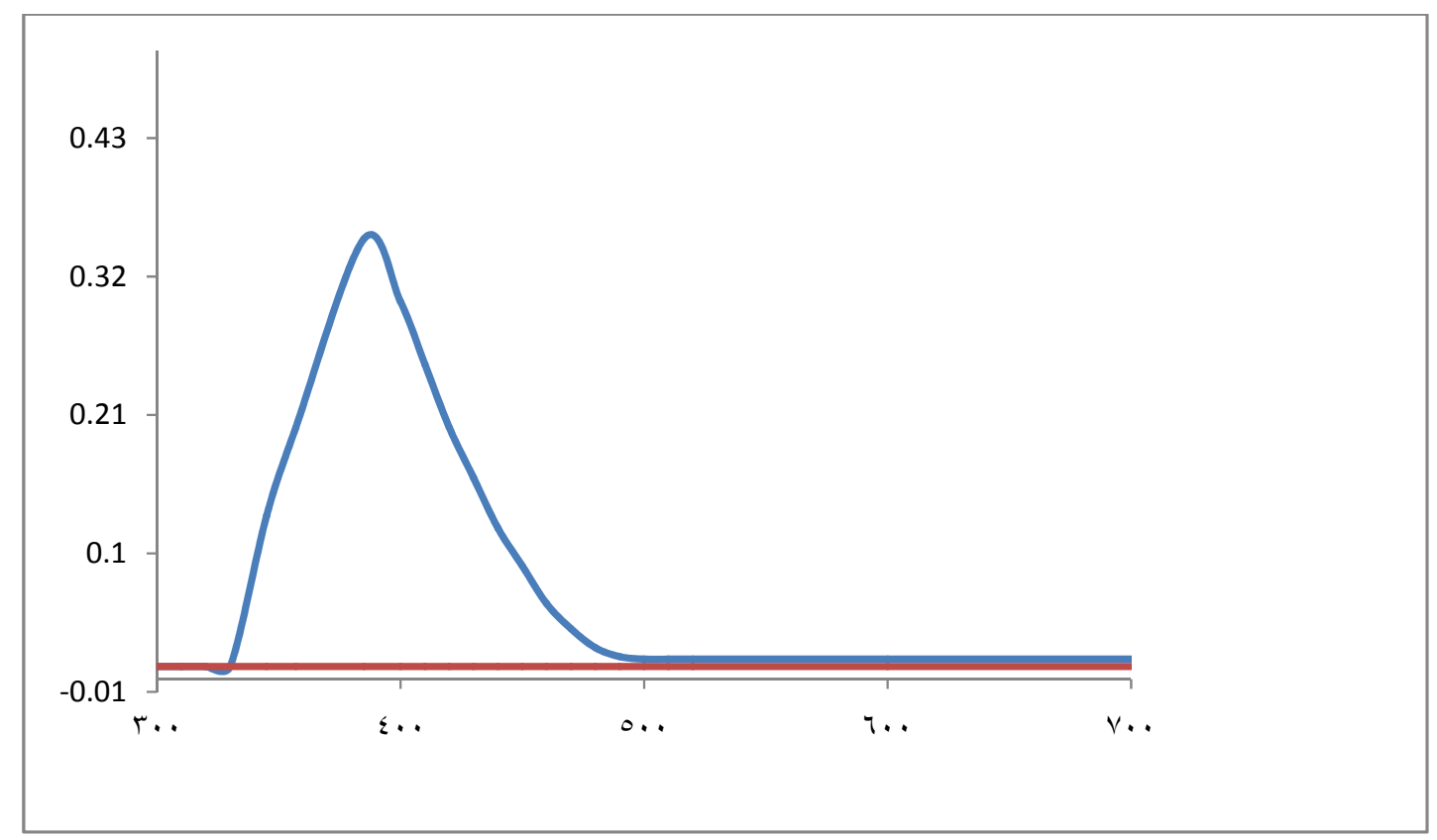

Figure 2. Absorption spectra of metformin hydrochloride product (B) against blank (A), metformin hydrochloride taken $(75 \mu \mathrm{g} / 25 \mathrm{~mL})$

The reaction variables were optimized by varying each variable, while keeping others constant for obtaining maximum absorbance. The oxidation reaction was found to be quantitative in sodium hydroxide medium .It was found that $5 \mathrm{ml}$ of $10 \mathrm{~N}$ sodium hydroxide solution give high sensitivity and this amount has been used for subsequent experiments . The effect of the amount of sodium hypochlorite on the absorbance was investigated. A maximum and constant absorbance was found with 1-5 $\mathrm{ml}$ of $0.1 \%$ sodium hypochlorite solution and $2.0 \mathrm{ml}$ has been used for subsequent experiments . The color reaction occurred at room temperature immediately and remained stable for at least six hours and a reaction time of 5 min was selected for reproducible results. Under the experimental conditions described, Beer's law is obeyed over the concentration range 0.5-4.0 $\quad \mu \mathrm{g} / \mathrm{mL} \quad$ (Figure 3) 


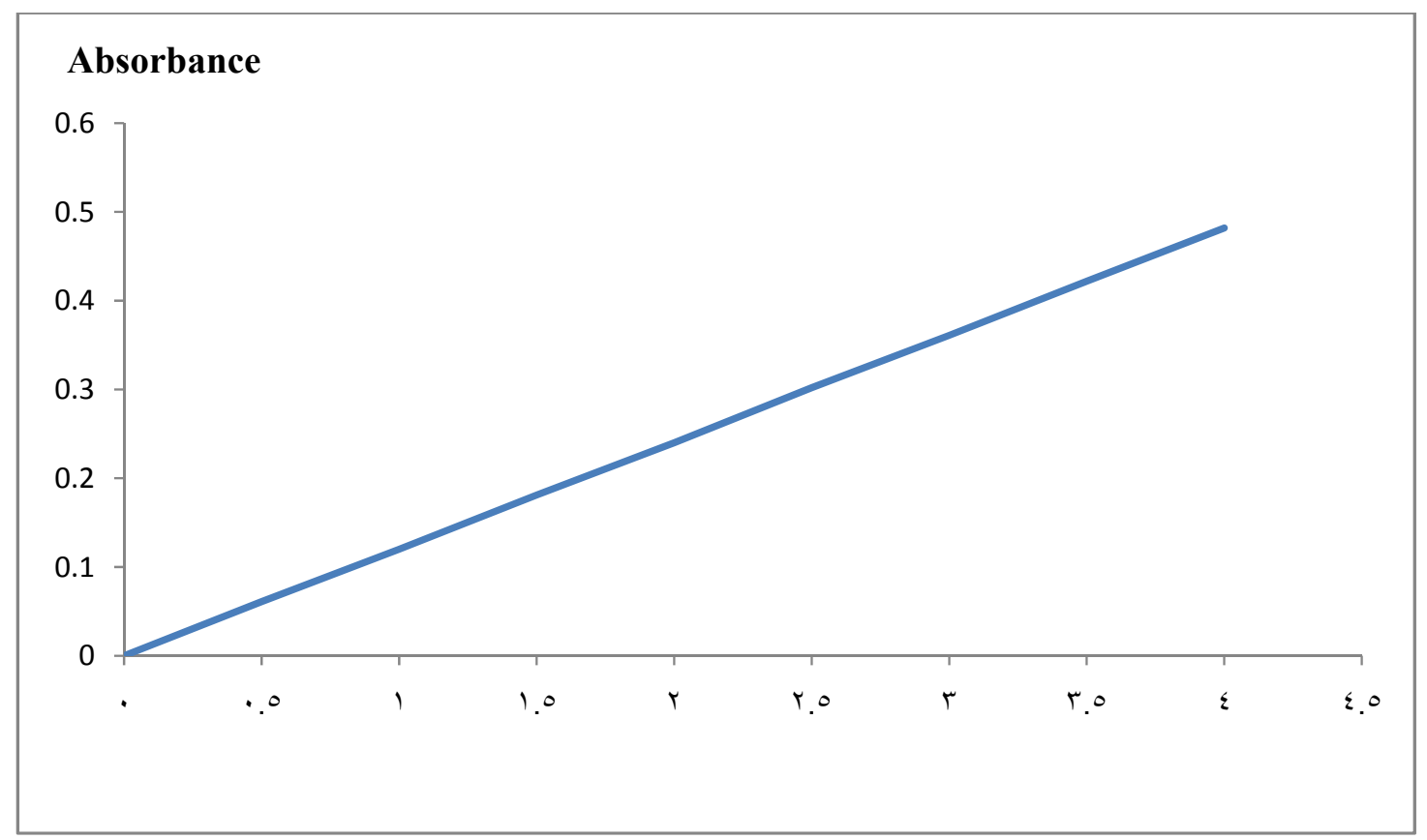

Figure 3. Calibration graph of metformin hydrochloride

A regression analysis of Beer 's law plot at $385 \mathrm{~nm}$ revealed a good correlation $(\mathrm{r}=0.9999, \mathrm{n}=8)$ the graph of the absorbance versus the concentration of metformin hydrochloride showed a low intercept $\left(6.097 \times 10^{-6}\right)$ and slope $(0.120)$ and is described by a regression equation $\mathrm{Y}$ $=\mathrm{ax}+\mathrm{b}$ (where $\mathrm{x}$ is the concentration of metformin hydrochloride in $\mu \mathrm{g} / \mathrm{mL}$, the absorbance is $\mathrm{Y}$, the slope is a and the intercept is $b$. The apparent molar absorptivity was $2 \times 10^{4} \mathrm{~L} \cdot \mathrm{mol}^{-1} \cdot \mathrm{cm}^{-1}$ .The limit of detection and quantification were evaluated $^{30}$.

$$
\begin{aligned}
& \text { LOD }=3.3 \frac{\text { So }}{\mathrm{b}} \\
& \text { LOQ }=10 \frac{\text { So }}{\mathrm{b}}
\end{aligned}
$$

\section{Stoichiometry of reaction}

The stoichiometry of reaction was investigated by the mole ratio
Where $b$ is the slope and So is the standard deviation of the regression line. The limit of detection was 0.083 $\mu \mathrm{g} \cdot \mathrm{ml}^{-1}$ and limit of quantification(as the lowest standard concentration which could be determined with acceptable accuracy and precision) was $0.25 \mu \mathrm{g} \cdot \mathrm{mL}^{-1}$.

\section{Accuracy and precision}

The accuracy and precision of the method was established by analyzing the pure drug solution at three different levels. The average recovery which is a measure of accuracy was $100 \pm 0.73$ revealing high accuracy of the method. The relative standard deviation (RSD), which is the indicator of precision is better than $\pm 1.8 \%$. The results are complied in Table 1.

method $^{31}$. The results obtained indicated the existence of 1:6 metformin hydrochloride - sodium 
hypochlorite. Thus the suggested study ${ }^{32}$. reaction might be written as in other

Table 1. Optical characteristics and statistical data for regression equation of the proposed method

\begin{tabular}{|l|l|}
\hline \multicolumn{1}{|c|}{ Parameters } & Value \\
\hline$\lambda$ max $(\mathrm{nm})$ & 385 \\
Beer's law limits $\left(\mu \mathrm{g} \cdot \mathrm{ml}^{-1}\right)$ & $0.5-4.0$ \\
Molar absorpitivity $\left(1 . \mathrm{mol}^{-1} \cdot \mathrm{cm}^{-1}\right)$ & $2.0 \times 10^{4}$ \\
Limit of detection $\left(\mu \mathrm{g} \cdot \mathrm{ml}^{-1}\right)$ & 0.083 \\
Limit of quantification $\left(\mu \mathrm{g} \cdot \mathrm{ml}^{-1}\right)$ & 0.25 \\
Determination coefficient $\left(\mathrm{r}^{2}\right)$ & 0.9999 \\
Regression equation $(\mathrm{Y}=\mathrm{a} \times+\mathrm{b})$ & \\
Slope $(\mathrm{a})$ & 0.125 \\
Intercept $(\mathrm{b})$ & $6.097 \times 10^{-6}$ \\
Recovery \% & $100 \pm 0.73$ \\
Relative standard deviation $(\%)$ & $<1.8$ \\
& \\
\hline
\end{tabular}<smiles>CN(C)C(=O)N=C(N)[O-]</smiles>

$\mathrm{CH}_{3}$<smiles></smiles>

$\mathrm{CH}_{3}$

$\beta$-diketone yellow- chromogen

Effect of interferences
The interfering effect of foreign species often accompanied with 
metformin hydrochloride in the pharmaceutical preparations were studied by adding different amounts of foreign species to $75 \mu \mathrm{g} / 25 \mathrm{ml}$ of metformin hydrochloride in solution and the recommended procedure for the determination of metformin hydrochloride was followed. The species are considered to interfere seriously if the cause aching of more than $2 \%$ in the absorbance obtained for metformin hydrochloride a lone ${ }^{33}$. Results of the recovery analysis are presented in Table 2. Excipients at the concentration show in Table [2] do not interfere with the assay .In addition recoveries in most cases were around $100 \%$.

Table 2. Determination of metformin hydrochloride in the presence of excipients

\begin{tabular}{|c|c|c|}
\hline Excipients & $\begin{array}{c}\text { Amount } \\
\text { taken, } \\
(\mu \mathrm{g} / \mathrm{ml})\end{array}$ & $\begin{array}{c}\text { Average } \\
\text { recovery, *\% }\end{array}$ \\
Talc & 500 & 99.98 \\
1000 & 100.06 \\
Mannitol & 500 & 100.09 \\
& 1000 & 99.92 \\
Mg-stearate & 500 & 100.05 \\
& 1000 & 100.03 \\
Starch & 500 & 100.06 \\
& 1000 & 100.03 \\
Microcrystalline & 500 & 99.92 \\
cellulose & 1000 & 99.90 \\
& & \\
\hline
\end{tabular}

* Average of five replicate determinations .

\section{Application of the proposed method}

The proposed method was successfully applied to the analysis of metformin hydrochloride in tablets and industrial waste water sample. The result of analysis for pharmaceutical formulations Table 3 were compared statistically by student t-test and by variance ratio F-test with those obtained by official method ${ }^{23}$ at $95 \%$ 
confidence level. The calculated $\mathrm{t}$ and $F$ values did not exceed the theoretical values indicating that there was no significant difference between the precision of proposed and official methods. The results of waste water sample Table 4 show that the recovery values obtained were closed to $100 \%$.

Table 3. Assay of metformin hydrochloride in pharmaceutical formulations

\begin{tabular}{|l|l|l|l|l|}
\hline $\begin{array}{c}\text { Pharmaceutical } \\
\text { formulation } \\
\text { supplied by NDI }\end{array}$ & $\begin{array}{l}\text { Amount of metformin hydrochloride * } \\
\text { Proposed method Official } \\
\text { method }\end{array}$ & t value & F value \\
\hline $\begin{array}{l}\text { Glucosam tablets } \\
(500 \mathrm{mg} / \text { tablet })\end{array}$ & 498.9 & 496.8 & 1.74 & 2.44 \\
\hline $\begin{array}{l}\text { Glucosam tablets } \\
(850 \mathrm{mg} / \text { tablet })\end{array}$ & 849.1 & 850.1 & 1.92 & 2.31 \\
\hline
\end{tabular}

*Mean of ten determinations, $\mathrm{t}$ values $(\mathrm{n}=10)$ at $95 \%$ confidence level, tabulated value $=2.262, \mathrm{~F}$ values $(\mathrm{n} 1$ and $\mathrm{n} 2=10)$ at $95 \%$ confidence level, tabulated value $=3.18$ 
Table 4. Determination of metformin $\mathrm{HCl}$ in industrial waste water sample

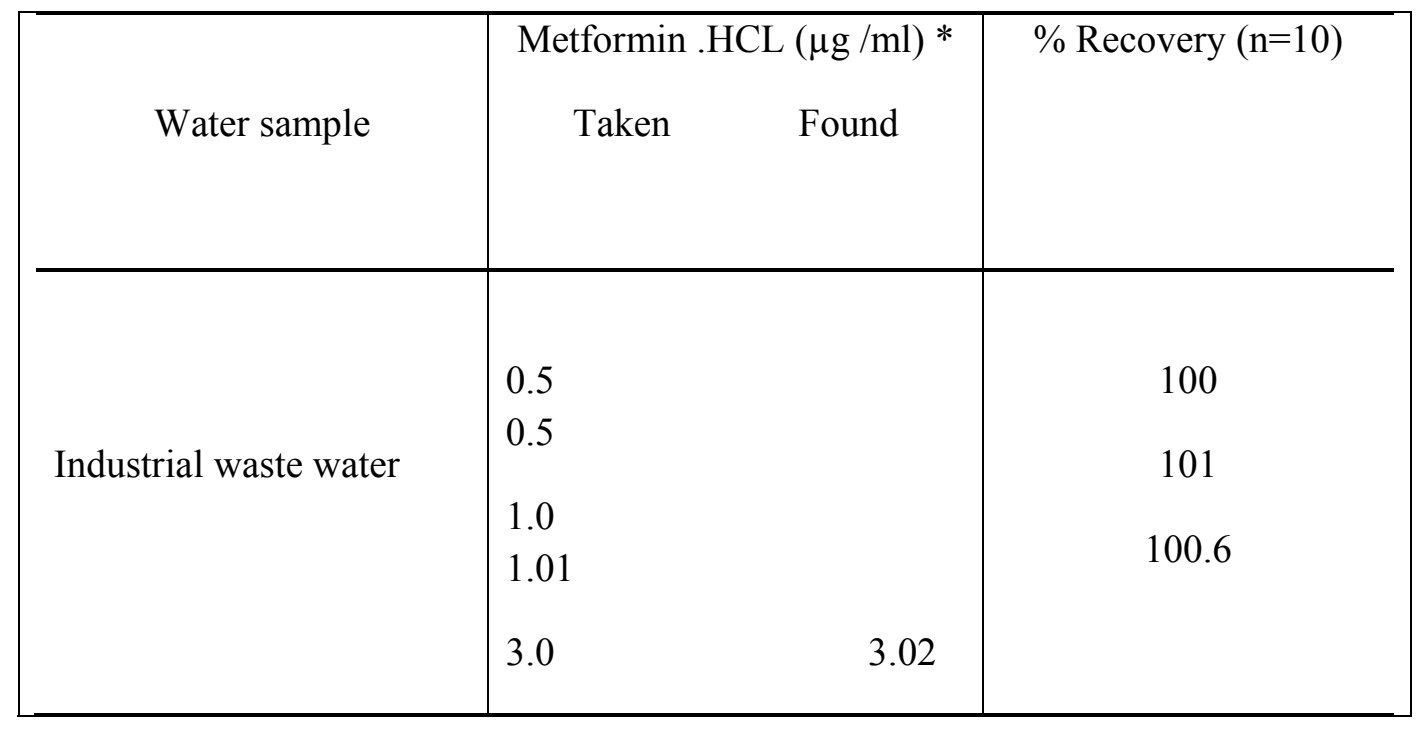

*Mean of ten determinations

Table 5. Content uniformity testing of metformin hydrochloride tablets using the proposed method

\begin{tabular}{|c|c|}
\hline Parameter & \% of the label claim \\
\hline Tablet NO. 1 & 100.52 \\
Tablet NO. 2 & 100.73 \\
Tablet NO. 3 & 99.35 \\
Tablet NO. 4 & 100.48 \\
Tablet NO. 5 & 99.38 \\
Tablet NO. 6 & 99.56 \\
Tablet NO. & 99.72 \\
Tablet NO. 8 & 100.25 \\
Tablet NO. 9 & 100.66 \\
Tablet NO. 10 & 99.71 \\
Mean (x ) & 100.03 \\
\% RSD & 0.54 \\
Max. allowed unit & $\pm 15 \%$ \\
\hline
\end{tabular}

Application of the method to content uniformity

The proposed method proved to be suitable for the content uniformity test, where a great number of assays on individual tablets are required. Data presented in Table 5 indicate that the proposed method can accurately and precisely quantitate metformin hydrochloride in its commercially 
available tablets. The mean percentage (with RSD) of the labeled claim found in ten tablets was $(0.54 \%)$ which fall within the content uniformity limits specified by the USP $30^{28}$.

\section{Conclusion}

In this work, a simple, rapid, precise and accurate spectrophotometric method was developed and validated for the determination of metformin hydrochloride in pharmaceutical preparations and industrial waste water samples. The method free from such experimental variables as heating or solvent extraction step. The method rely on the use of simple and cheap chemicals and techniques and can be used for rapid routine determination and quality control of metformin hydrochloride in pure form, bulk sample, pharmaceutical preparations and real industrial waste water sample.

\section{References}

1. The pharmaceutical codex, Incorporating the British pharmaceutical codex, $11^{\text {th }} \mathrm{Edn}$, pharmaceutical press, London 1979, p. 544

2. Nelson R, Spann D, Elliott.D, et al. Evaluation of theantihyperglycemic drug metformin in normal and diabetic cats. J Vet Int Med 2004;18:18-24

3. Wang S, Kusuhara H, Kato Y, et al. Involvement of organic cation transporter 1 in the lactic acidosis caused by metformin ,"molecular pharmacology, 2003;16 (4):844-8.

11. KolteB, Raut B, Deo A, Shinde.D. Simultaneous HPLC determination of pioglitazone and metformin in pharmaceutical dosage form. J
4. Zarghi A, Foroustan S, Shafaati A, Khoddam.A. Rapid determination of metformin in human plasma using ion-pair HPLC. J Pharma Biomed Anal 2003;31(1):197-200.

5. Bonfigli A, Manfrini S, Testa R, Coppa G. Determination of plasma metformin by new cation exchange HPLC technique, The Drug Monit. 1999;21(31):330-4

6. Ali M, Maha.F, Charl A. Determination of metformin in human plasma using normal phase high performance liquid chromatography. Saudi pharmaceut J 2006,14(2),108-14

7. Amini $\mathrm{H}$, Alhamdani $\mathrm{A}$, Gazerani.P. Determination of metformin in human plasma by HPLC. J Chromatogr B 2005;824(1-2):319-22

8. Aburuz, Millership J, Elany J. Determination of metformin in plasma using a new ion-pair solid phase extraction technique and ion-pair liquid.

9. Rahman B, Ahmed M, Islam.M, et al. Simultaneous HPLC determination of metformin hydrochloride and rosiglitazone maleate in pharmaceutical-dosage form Research. J Med Med Sc 2007;2(2):115-21.

10. Ghassempor A, Ahmadi M, Ebrahimi S, Enein $\mathrm{H}$. Simultaneous determination of metformin and glyburide in tablets by HPLC. Chromatographia 2006;64:101-104.

Chromatoger Sci 2004;42(1):27-31

12. Chen X, Gu Q, Qiu F, Zhong.D. Rapid determination of metformin 
in human plasma by liquid chromatography- tandem mass spectrometry method. J chromatogr B,2004,802,377-81.

13. Cheny C, Chou.C. Determination of metformin in human plasma by HPLC with spectrophotometric detection. J Chromatogr B Biomed Sci 2001;762(1):51-8.

14. Heinig K, Bucheli.F. Fast liquid chromatographic- tandem mass spectrometric(LC-MS-MS) determination of metformin in plasma samples. J pharma Biomed Anal 2004;34(5):1005-11.

15. Kar M, Choudhury P. HPLC method for estimation of metformin. hydrochloride in formulated microspheres and tablet dosage form. Indian J Pharmaceut S 2009;71(3):318-20

16. Abo-dan M, ShourS, Abo.dan H. Conductometric titration of metformin in pure form and in pharmaceutical preparations using sodium-tetraphenylborate and cetylpyridinium bromide. Asian J Chem 2001;13:1-7

17. Wang Z, Zhang Z Wf, Zhang X. Sensitive flow-injection chemiluminescence determination of metformin based on $\mathrm{N}$ bromosuccinimide-fluorescein system. Anal Lett 2003;36(12):2683-97.

18. Karine L, Santos M, Lima C. A catalytic multi-pumping flow system for chemiluminometric determination of metformin. Anal Bioanal .Chem 2005;382:452-457.

19. Chao.H, Zhang.Z, Deyong H, Xiong.Y. Chemiluminescence determination of metformin based on hydroxyl radical reaction and molecularly imprinted polymer online enrichment. Anal Bioanal Chem 2006;385:128-33.

20. Edward P, Shery.F. Non-aqueous capillary electrophoresis for the determination of metformin ,phenformin and glyburide in human plasma. J Chromatogr B 2006;843(1):94-99.

21. Dobaria N, Shan Sm Rajput S. Development of novel plastic membrane ion - selective electrode for metformin hydrochloride. Indian $\mathrm{J}$ Pharmaceutl Sc 2006;68(5):562-5.

22. Slawomira S, Valentine M, Witold $C$, et al. Direct determination of metformin in urine by adsorptive catalytic square-wave voltammetry. J pharma Biomed Anal 2007;45 (2):275-81.

23. British pharmacopeia. Her Majesty, Stationary Office, London, 2009,P.3813.

24. Ashour A, Kabbani R. Direct spectrophotometric determination of metformin hydrochloride in pure form and in drug formulations. Anal Lett, 2003;36(2):361-70.

25. Hassan S, Mahmoud W, Elmosallamy M, Othman A. Determination of metformin in pharmaceutical preparations using potentiometry,spectrofluorimetry and uv-visible spectrophotometry. Anal Chim Acta 1999;378(13):299-311.

26. Mubeen G, Noor.K . Spectrophotometric method for analysis of metformin hydrochloride. Indian J Pharmaceutl Sc 2009;71(1):100-2.

27. Araynce M, Sultana N, Zuberi M, Siddiqui.F. Spectrophotometric 
quantitation of metformin in bulk drug and pharmaceutical formulations using multivariate technique. Indian $\mathrm{J}$ pharmaceut $\mathrm{S}$ 2009;71(3):331-5.

28. The United State Pharmacopeia Convention, Inc,32-N 27,2009,P.2905.

29. Kolthoff IM, Belcher R. Stenger.V.A and Matsuyama.G. Volumetric Analysis. Interscience publishers, New York, Volume III, 1957, P.580

30. Bassavaiah K, Somashekar B. Quantitation of rantidine in pharmaceuticals by titrimetry and spectrophotometry using dichromate as the oxidimetric reagent. Journal Iranian Chem Soc 2007;4:78-88 .

31. Bouer HH, Christan GD, Oreily JE. Instrumental analysis. Allyn and Bacon ,Inc, Boston, 1978,PP. 178-9 .

32. Marczenko Z. Spectrophotometric determination of elements. Ellits Howard, Chaichester, 1976, p. 399

33. Hung SCh, Qu CL, Sh WuS. Spectrophotometric determination of uranium with 2-(3,5) dibromo-2pyridylazo-5- diethylaminophenol in the presence of an ionic surfactant. Talanta 1982;29:62931 . 